\title{
Molecular and Cellular Aspects of Iron-induced Hepatic Cirrhosis in Rodents
}

\author{
Antonello Pietrangelo, Rossana Gualdi, Giovanna Casalgrandi, Giuliana Montosi, and Ezio Ventura \\ Department of Internal Medicine, Chair and Division of Internal Medicine II, University of Modena, 41100 Modena, Italy
}

\begin{abstract}
Hepatic fibrosis and cirrhosis are common findings in humans with hemochromatosis. In this study we investigated the molecular pathways of iron-induced hepatic fibrosis and evaluated the anti-fibrogenic effect of vitamin $E$. Male gerbils were treated with iron-dextran and fed a standard diet or a $\alpha$-tocopherol enriched diet $(250 \mathrm{mg} / \mathrm{Kg}$ diet $)$. In gerbils on the standard diet at 6 wk after dosing with iron, in situ hybridization analysis documented a dramatic increase of signal for collagen mRNA around iron foci onto liver fat storing cells (FSC), as identified by immunocytochemistry with desmin antibody. After 4 mo, micronodular cirrhosis developed in these animals, with nonparenchymal cells surrounding hepatocyte nodules and expressing high level of TGF $\beta$ mRNA. In this group, in vivo labeling with $\left[{ }^{3} \mathrm{H}\right]-$ thymidine showed a marked proliferation of nonparenchymal cells, including FSC. In iron-dosed gerbils on the vitamin E-enriched diet for $4 \mathrm{mo}$, in spite of a severe liver iron burden, a normal lobular architecture was found, with a dramatic decrease of collagen mRNA accumulation and collagen deposition. At the molecular level, a total suppression of nonparenchymal cell proliferation was appreciable, although expression of collagen and TGF $\beta$ mRNAs was still present into microscopic iron-filled nonparenchymal cell aggregates scattered throughout the hepatic lobule. In conclusion, our study shows that anti-oxidant treatment during experimental hepatic fibrosis arrests fibrogenesis and completely prevents iron induced hepatic cirrhosis mainly through inhibition of nonparenchymal cell proliferation induced by iron. (J. Clin. Invest. 1995. 95:1824-1831.) Key words: iron overload $\bullet$ collagen gene $\bullet$ liver fibrosis • vitamin E $\cdot$ fat-storing cells
\end{abstract}

\section{Introduction}

Untreated hepatic iron overload due to genetic defect(s) of iron metabolism (e.g., genetic hemochromatosis, $\mathrm{GH})^{1}$ or secondary to other disorders (e.g., thalassemic syndromes, multiple trans-

This work was presented in part at the Annual Meeting of the European Association for the Study of the Liver held in Paris, September 1993 (J. Hepatol. 102, A868, 1993).

Address correspondence to A. Pietrangelo, M.D., Ph.D., Department of Internal Medicine, Policlinico, Via del Pozzo 71, 41100 Modena, Italy. Phone: 59-379250; FAX: 59-367627.

Received for publication 7 June 1994 and in revised form 9 November 1994.

1. Abbreviations used in this paper: FSC, fat storing cells; GH, genetic hemochromatosis; MDA, malondialdehyde.

J. Clin. Invest.

(C) The American Society for Clinical Investigation, Inc.

0021-9738/95/04/1824/08 $\$ 2.00$

Volume 95, April 1995, 1824-1831 fusions, alcoholic cirrhosis) leads to hepatic fibrosis and cirrhosis $(1,2)$. In individuals with $\mathrm{GH}$, early periportal fibrosis may occur with heavy parenchymal iron deposition, but in the absence of obvious cell necrosis and inflammation $(3,4)$, suggesting that excess tissue iron provides a direct stimulus to collagen synthesis. In fact, experimental in vivo iron overload enhances the accumulation of hepatic collagen type I mRNA in rodents (5), specifically in liver fat storing cells (FSC) (6). It has been proposed that cellular iron toxicity is mainly due to iron-induced free radical attack (7) and that iron-induced lipid peroxidation in vitro stimulates collagen gene transcription (8). Thus, it is likely that also during in vivo chronic iron overload iron-generated free-radical species or lipid-peroxidation byproducts mediate the fibrogenic process. As a consequence, a rational therapeutical approach would attempt to counteract the oxidative attack mediated by iron.

In vivo models of hepatic siderosis have provided biochemical, ultrastructural or histopatological evidences for sinusoidal or periportal fibrosis (9-12). Recently, using a new model of iron overload (i.e., parenteral iron in the gerbil), Carthew and co-workers have been able to produce micronodular cirrhosis (13-15). In the gerbil, iron accumulates into nonparenchymal cell aggregates including Kupffer cells leading to collagen deposition and progression toward hepatic cirrhosis within 6-12 wk (13). Thus, the gerbil's rapid fibrosing response to iron offers the unique opportunity of studying the molecular basis of ironinduced collagen gene activity and examining the effectiveness of therapeutical interventions with anti-fibrogenic agents.

The present study was designed to investigate the molecular mechanisms of iron-induced liver fibrosis in the gerbil and, specifically, to evaluate the effectiveness of anti-oxidant treatment (i.e., dietary vitamin $\mathrm{E}$ supplementation) on preventing the molecular and pathological progression toward hepatic cirrhosis.

\section{Methods}

\section{Animals}

Male gerbils (6 wk of age) were (a) subcutaneously dosed with $1 \mathrm{mg} /$ $\mathrm{g}$ body wt of iron-dextran (Sigma Chemical Co., St. Louis, MO) and fed a standard pellet diet (Fratelli Piccioni, Brescia, Italy) (vitamin E content $50 \mathrm{mg} / \mathrm{Kg})(n=14)$; (b) subcutaneously dosed with $1 \mathrm{mg} / \mathrm{g}$ body wt of dextran alone and fed a standard diet $(n=14) ;(c)$ subcutaneously dosed with $1 \mathrm{mg} / \mathrm{g}$ body wt of iron-dextran and fed a vitamin E-enriched diet $(250 \mathrm{mg} / \mathrm{Kg}$ diet $)(n=14) ;(d)$ subcutaneously dosed with $1 \mathrm{mg} / \mathrm{g}$ body wt of dextran and fed a vitamin $\mathrm{E}$ enriched diet $(n$ $=14$ ). The vitamin was present as $\alpha$-tocoferyl acetate. At $6 \mathrm{wk}$ and 4 mo after dosing, 4 and 6 animals of each group, respectively, were killed by decapitation and liver was processed for chemical, histological, immunohistochemical, and molecular analyses ( see below). Blood samples were collected for biochemical evaluations. All animals used were treated with human care according to national guidelines.

\section{LIGHT MICROSCOPY STUDIES}

Thin liver slices were cut, fixed in a $4 \%$ solution of paraformaldehyde

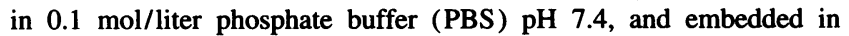
paraffin. Five nm sections were prepared and stained with hematoxylin and eosin and Perls' Prussian blue. 
IN SITU HYBRIDIZATION

In situ hybridization analysis was performed on liver tissue frozen in liquid nitrogen and stored at $-80^{\circ} \mathrm{C}$.

Generation of ${ }^{35}$ S-labeled RNA probes. A EcoRI-Hind III 1300 bp fragment of rat pro $\alpha_{1}$ (I) collagen cDNA (16) was subcloned in PGEM1 plasmid (17) and a SmaI 592-bp fragment of human TGF $\beta$ cDNA (18) was subcloned in pGEM blue (Promega, Madison, WI). To generate run-off transcripts of the "antisense" or "sense"' strands, respectively, $1 \mu \mathrm{g}$ of plasmids linearized with either Hind III or EcoRI restriction endonucleases and 10 Units of T7 or SP6 RNA polymerases were added to a $10 \mu \mathrm{l}$ reaction mixture containing $100 \mu \mathrm{Ci}$ of ${ }^{35} \mathrm{~S}$-uridine-5' athiotriphosphate $(1,250 \mathrm{Ci} / \mathrm{mmole}$, Amersham, UK), $1 \mathrm{mmol} /$ liter each of adenosine, cytidine and guanosine-5'-triphosphate, $10 \mathrm{mmol} / \mathrm{liter}$ DTT, $25 \mathrm{U}$ of human placental RNAse inhibitor, $6 \mathrm{mmol} /$ liter $\mathrm{MgCl}_{2}$, $40 \mathrm{mmol} /$ liter Tris- $\mathrm{HCl}, \mathrm{pH} \mathrm{7.5,2} \mathrm{mmol} /$ liter spermidine, $10 \mathrm{mmol} /$ liter $\mathrm{NaCl}$, and incubated $1 \mathrm{~h}$ at $37^{\circ} \mathrm{C}$ for $\mathrm{T} 7$ or at $40^{\circ} \mathrm{C}$ for SP6 RNA polymerase. Plasmid DNA was removed by digestion with $2 \mathrm{U}$ of RNAse free-DNA seI at $37^{\circ} \mathrm{C}$ for $15 \mathrm{~min}$, followed by phenol-chloroform extraction and ethanol precipitation. To increase the penetration into tissue, the size of the ${ }^{35} \mathrm{~S}$-collagen riboprobe was adjusted to 50 200 bases length by a controlled alkaline hydrolysis in $80 \mathrm{mmol} /$ liter $\mathrm{NaHCO}_{3}, 120 \mathrm{mmol} /$ liter $\mathrm{Na}_{2} \mathrm{CO}_{3}(\mathrm{pH} \mathrm{10.2}), 10 \mathrm{mmol} /$ liter DTT at $60^{\circ} \mathrm{C}$. After neutralisation in $0.2 \mathrm{~mol} /$ liter sodium acetate $(\mathrm{pH} 6.0), 1 \%$ acetic acid, $120 \mathrm{mmol} /$ liter $\mathrm{Na}_{2} \mathrm{CO}_{3}(\mathrm{pH} \mathrm{10.2)}$ and $10 \mathrm{mmol} /$ liter DTT and ethanol precipitation, RNA probes were stored at $-80^{\circ} \mathrm{C}$.

In situ hybridization. 5- $\mu \mathrm{m}$ thick frozen tissue sections were collected onto 3-aminopropyl-triethoxysilane coated slides, air dried, fixed in a $4 \%$ solution of paraformaldehyde in $0.1 \mathrm{M}$ PBS ( $\mathrm{pH} 7.4$ ) containing $5 \mathrm{mmol} /$ liter $\mathrm{MgCl}_{2}$ for $15 \mathrm{~min}$. Prehybridization, hybridization and washings of slides were performed as previously described (6).

\section{RNA Extraction and Northern Blot Analysis}

Total hepatic RNA was purified using the acid guanidinium thiocyanatephenol-chloroform extraction method (19) and 40-45- $\mu \mathrm{g}$ aliquots were electrophoresed under denaturing conditions blotted to Hybond $\mathrm{C}$ extra filters (Amersham, UK) and hybridized with the various probes as described (20). The DNA probes were labeled with $\left[{ }^{32} \mathrm{P}\right] \mathrm{dCTP}$ using the Promega random primer labeling kit (Prime-a-Gene) according to the manufacturer's directions. For quantitative determinations, autoradiograms were scanned with a laser densitometer (LKB Ultroscan, LKB Diagnostics, Piscataway, NJ) making sure that the exposure of the films was in the linear range. The values were corrected by the amount of rRNA loaded in each lane as determined by hybridization with the cDNA probe for the 18S rRNA on the same filter, and calculated as previously reported (21)

\section{Probes}

The $\mathrm{p} \alpha_{1} \mathrm{R}_{1}$ cDNA for rat pro- $\alpha_{1}(1)$-collagen (16), the human TGF $\beta$ cDNA (18) and the $1 \mathrm{~S}$ rRNA probe (22) were generous gifts of $\mathrm{C}$. Genovese (Farmington, CO), J. Mead (Providence, RI) and D. A. Shafritz (Bronx, NY), respectively.

\section{IMMUNOCYTOCHEMISTRY}

$7-\mu \mathrm{m}$ sections from frozen liver specimens were collected onto clean slides treated as specified for the in situ hybridization analysis, fixed with a $4 \%$ solution of paraformaldehyde in $0.1 \mathrm{~mol} / \mathrm{liter}$ phosphate buffer (PBS) pH 7.4, washed twice with PBS and incubated with the first antibody: mouse monoclonal anti-human desmin (D33; Dakopatts, Glostrup, Denmark) diluted 1:200 in solution A (10\% fetal bovine serum in RPMI 1640). All incubation steps were carried out at room temperature, in a humidified chamber, for $30 \mathrm{~min}$. Each step was followed by two washes for $5 \mathrm{~min}$ each in Tris $\mathrm{HCl}$ buffered saline (TBS, pH 7.5). A rabbit antiserum directed against mouse IgG (Dakopatts, Glostrup, Denmark) diluted 1:20 in solution A containing 10\% rat serum was used as linking antibody. After incubation with APAAP complex (alkaline phosphatase/mouse monoclonal anti-alkaline phosphatase) (Dakopatts, Glostrup, Denmark) diluted 1:50 in solution A, the chromogenic reaction was developed in solution B containing Tris $\mathrm{HCl} 0.05$ mol/liter ( $\mathrm{pH} \mathrm{8.7)}, \mathrm{NaCl} 0.15 \mathrm{~mol} /$ liter, $50 \mathrm{mg} \%$ (wt/vol) levamisole,
$0.75 \mathrm{~g} \%$ (wt/vol) 2-amino-2 metil-propandiolo, $70 \mathrm{mg} \%$ (wt/vol) naphthol AS-BI-phosphate sodium salt, $0.9 \%$ (vol/vol) $N-N$ dimethylformamide, $29 \mathrm{mg} \%$ (wt/vol) sodium nitrite, $0.4 \%$ (vol/vol) new fucsin (stock solution $=5 \mathrm{~g} \mathrm{\%}$ in $2 \mathrm{~N} \mathrm{HCl}$ ).

FAT-STORING CELLS IN VIVO LABELING WITH $\left[{ }^{3} \mathrm{H}\right]$ THYMIDINE Four gerbils for each group were injected intravenously with $100 \mu \mathrm{Ci}$ / $100 \mathrm{~g}$ body wt methyl- $\left[{ }^{3} \mathrm{H}\right]$ thymidine (Amersham, UK, specific activity 6.7 $\mathrm{Ci} / \mathrm{mmol}$ ) $60 \mathrm{~min}$ before killing. Processing of liver samples and immunocytochemistry were performed as specified above. Afterwards, the sections were dipped in Kodak NTB-2 emulsion and exposed to autoradiography at $4^{\circ} \mathrm{C}$ for 1,2 , and $4 \mathrm{wk}$ in the presence of silica gel. After development in Kodak D19 developer and fixation in Kodak Fixer. the slides were counterstained with $\mathrm{H} \& \mathrm{E}$, mounted, and viewed under light microscope. Local proliferation of FSC was examined by counting the number of desmin-positive cells showing autoradiographic grains above the nucleus in five different fields $(\times 40)$ and expressed as percentage of the total number of desmin-positive cells in the same field.

\section{BIOCHEMICAL EVALUATIONS}

Iron content in samples from liver tissue was analysed by atomic absorption spectroscopy, as reported (23).

Plasma vitamin E was determined as previously described (24). The same procedure was used for determination of vitamin $\mathrm{E}$ in liver samples, following extraction from $10 \%$ (wt/vol) liver homogenate made in $0.25 \mathrm{~mol} /$ liter sucrose. Serum AST and ALT were determined by standard automated laboratory methods.

Since iron exerts its toxic effect on the liver mainly through an oxidative attack, we also measured hepatic content of malondialdehyde (MDA), one of the commonly measured breakdown products of membrane lipid peroxidation, which is usually increased in iron-treated animals (7). Hepatic MDA concentration was measured in 5\% liver homogenate ( $w t / v o l$ ) made in trichloroacetic acid immediately after sacrifice, following the method described by Recknagel et al (25).

As a measure of liver collagen deposition, we determined the concentration of L-hydroxyproline according to published methods ( 26 , 27). Briefly, the pellet obtained after centrifugation of liver homogenate was subjected to acid hydrolysis in $6 \mathrm{~mol} / \mathrm{L} \mathrm{HCL}$, treated with chloramine $\mathrm{T}$ to obtain oxidation of L-hydroxyproline to pyrrole, and the chromophore development was obtained with $p$-dimethylaminobenzaldehyde.

\section{STATISTICAL ANALYSIS}

All data reported in Table I represent mean \pm SD. Significant difference from control (group b) were analysed by the Student $t$ test.

\section{Results}

Table I shows results of the biochemical determinations made in all groups. Liver iron content was increased by 20-30-fold in the iron-treated groups (i.e., group a and group c), regardless of the addition of vitamin $\mathrm{E}$ to the standard diet. The iron treatment determined a significant decrease of hepatic vitamin $\mathrm{E}$ content in gerbils on the standard diet (group a), whereas hepatic vitamin $\mathrm{E}$ was significantly increased in gerbils on the vitamin E supplemented diet (group c). As far as the vitamin E supplemented groups is concerned, the increase in hepatic vitamin $E$ found in untreated animals of group $d$ was significantly higher than that found in treated animals of group $c$. This finding reinforces the concept that hepatic iron overload leads per se to a significant consumption of hepatic antioxidant defences such as $\alpha$-tocopherol.

Apparently, the iron-treatment did not lead to additional necrotic events, since serum level of transaminases in irontreated gerbils was not significantly different from that of control gerbils (Table I). As expected, hepatic MDA was significantly increased in gerbils of group a as compared to those of group $b$. 
Table I. Biochemical Evaluations in the Gerbils at 4 Months after Dosing with Iron

\begin{tabular}{|c|c|c|c|c|c|c|c|c|}
\hline Group & Treatment & $n$ & ALT & Liver iron & Liver $\alpha$-tocopherol & Collagen mRNA & Liver collagen & Liver MDA \\
\hline & & & $U / L$ & $\mu g / g d r y w t$ & $\mu g / m g$ protein & arbitrary units & $\mathrm{mg} / \mathrm{g}$ liver & nmol/mg protein \\
\hline A & Iron-dextran & 6 & $134 \pm 58$ & $11976 \pm 988^{* *}$ & $158 \pm 45^{*}$ & $10.2 \pm 2.3 * *$ & $7.6 \pm 0.7 * *$ & $0.850 \pm 0.115^{* *}$ \\
\hline B & Dextran & 6 & $113 \pm 35$ & $431 \pm 80$ & $230 \pm 12$ & $1.0 \pm 0.3$ & $1.7 \pm 0.4$ & $0.220 \pm 0.035$ \\
\hline $\mathrm{C}$ & Iron-dextran + vitamin $\mathrm{E}$ & 6 & $85 \pm 27 *$ & $10877 \pm 890^{* *}$ & $499 \pm 75^{* *}$ & $2.4 \pm 0.5^{*}$ & $2.4 \pm 0.4$ & $0.440 \pm 0.108 *$ \\
\hline D & Dextran + vitamin E & 6 & $78 \pm 29 *$ & $389 \pm 89$ & $532 \pm 54 * *$ & $0.8 \pm 0.3$ & $1.4 \pm 0.3$ & $0.205 \pm 0.074$ \\
\hline
\end{tabular}

Data are mean $\pm \mathrm{SD} . * P<0.05 ; * * P<0.001$ (Student $t$ test). Collagen mRNA data are expressed as densitometric arbitrary units. The mean value of the control group B was set to 1.0: collagen mRNA values were normalized to the signal of rRNA (see Methods for details).

In control gerbils, liver architecture was normal throughout the study with the small nonparenchymal cell aggregates showing some iron deposition secondary to microscopic hemorragic necrosis (14) (Fig. $1 \mathrm{~A}$ ).

\section{Effects of iron overload}

Pathology. Liver pathology of gerbils at six wk and at 4 mo after dosing with iron was that described by Carthew et al. (9, 14), with small iron-filled nonparenchymal cell aggregates at 6 wk (Fig. $1 B$ ) and evident liver nodularity at $4 \mathrm{mo}$, with nodules of hepatocytes surrounded by a large number of ironladen nonparenchymal cells (Fig. 1 C). Some degree of iron overload was also found into hepatocytes of iron-treated gerbils.
As expected, hepatic collagen content was significantly increased after 4 mo of iron dosing (Table I).

Molecular aspects of liver fibrogenesis. The lobular and cellular expression of collagen type I gene was investigated by in situ hybridization analysis with a specific collagen cRNA probe (Fig. 2). In iron-dosed gerbils of group a), a dramatic increase of collagen gene expression was detected in cells surrounding the iron-foci at $6 \mathrm{wk}$ (Fig. $2 \mathrm{~B}$ ). When control slides were processed with the sense cRNA probe no specific hybridization signal was detected (Fig. $2 C$ ). After $4 \mathrm{mo}$, a large number of collagen expressing cells around the nodules (Fig. $2 D$ ). In control gerbils, the expression of collagen gene was low (Fig. $2 A$ ). To quantitate the increase of collagen mRNA
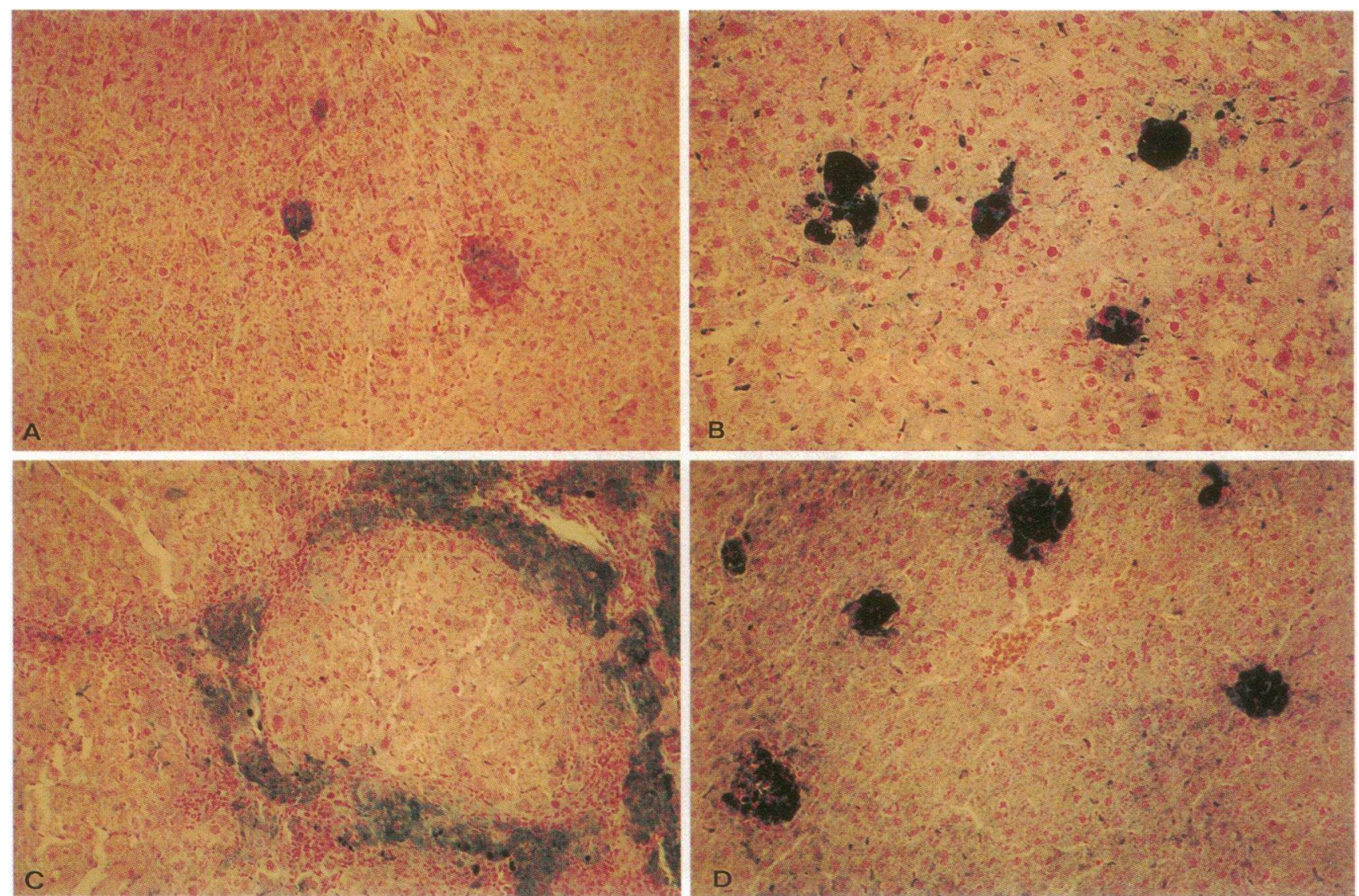

Figure 1. Iron accumulation in the liver of iron-treated gerbils (Perls' Prussian blue stain). (A) Small nonparenchymal cell aggregates of control gerbils contain some iron, while $(B)$ they are filled with iron at six wk after iron injection. $(C)$ At four mo after dosing with iron, large hepatocyte nodules are surrounded by iron-laden nonparenchymal cells, while in iron-treated vitamin E-fed rats $(D)$ no progression toward hepatic cirrhosis is seen with the small iron-filled nonparenchymal cell aggregates found throughout the study $(\times 213)$. 

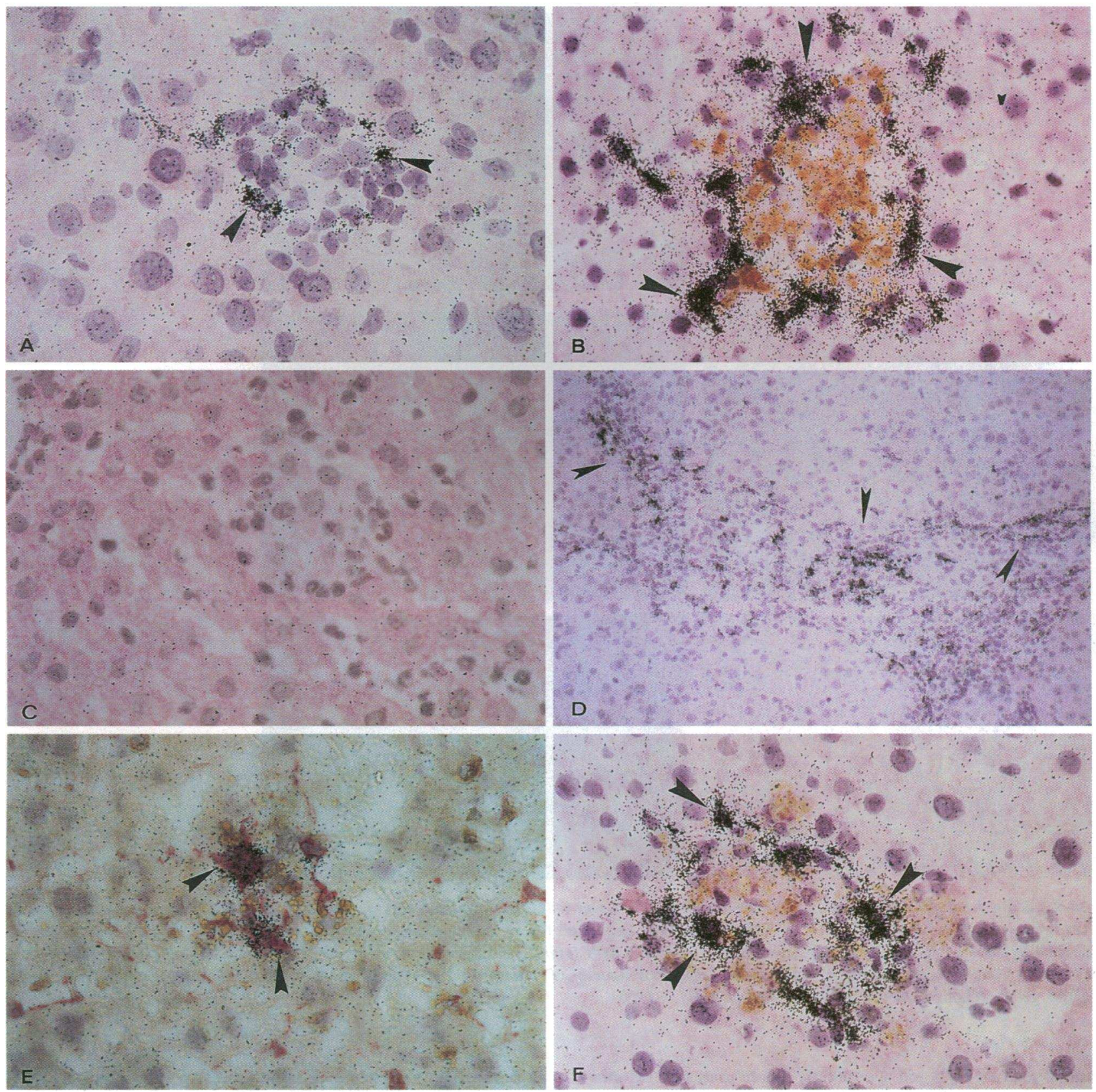

Figure 2. Localization of collagen type I mRNA in iron-loaded gerbils. Liver tissue sections from control $(A)$ and iron-intoxicated gerbils on a standard diet for $6 \mathrm{wk}(B, C$, and $E)$ and $4 \mathrm{mo}(D)$ or on a vitamin-E enriched diet for $4 \mathrm{mo}(F)$ were processed for in situ hybridization analysis $(A, B, C, D$, and $F)$ or immunocytochemistry with anti-desmin antibody followed by in situ hybridization analysis $(E)$ with specific pro- $\alpha_{1}$ (I)collagen ${ }^{35}$ S-antisense $(A, B, D, E$, and $F)$ or "sense" $(C)$ cRNA probes synthesised in vitro using T7 or SP6 RNA polymerases, respectively. The bright field microphotographs show a dramatic increase of the accumulation of silver grains onto cells surrounding iron-filled foci in the liver of gerbils at $6 \mathrm{wk}$ after iron injection (arrowheads)(B) as compared with control liver $(A)$, with no appreciable signal over the background level onto hepatocytes. No specific hybridization signal was detected with the "sense" probe $(C)$. At 4 mo after iron treatment, a stream of cells expressing high level of collagen transcripts (arrowheads) surrounds hepatocyte nodules $(D)$. In a tissue section of iron-laden liver which was first processed for immunocytochemistry with anti-desmin antibody and then for in situ hybridization analysis $(E)$, the silver grains which indicate specific hybridization signal for collagen co-localize with desmin staining (red) onto nonparenchymal cells around iron-filled foci (arrowheads) In iron-treated gerbils on a vitamin E-enriched diet activation of collagen is confined to cells around small iron-filled foci $($ arrowheads $)(F)$. $(A, B, C, E$ and $F \times 655 ; D, \times 213)$.

expression in the whole liver of iron-intoxicated animals, we used a Northern blot analysis of total liver RNA. As shown in Table 1, iron-dosing determined a 8-12 fold increase of collagen mRNA accumulation after 4 mo. To confirm that the liver cells expressing high level of collagen transcripts in the iron- treated gerbils were indeed FSC, as found in other experimental models of liver fibrosis $(17,28)$, we performed immunohistochemistry with desmin antibody followed by in situ hybridization with a collagen cRNA probe. Fig. 2 shows results of a representative experiment. At $6 \mathrm{wk}$ after iron dosing, the hybrid- 

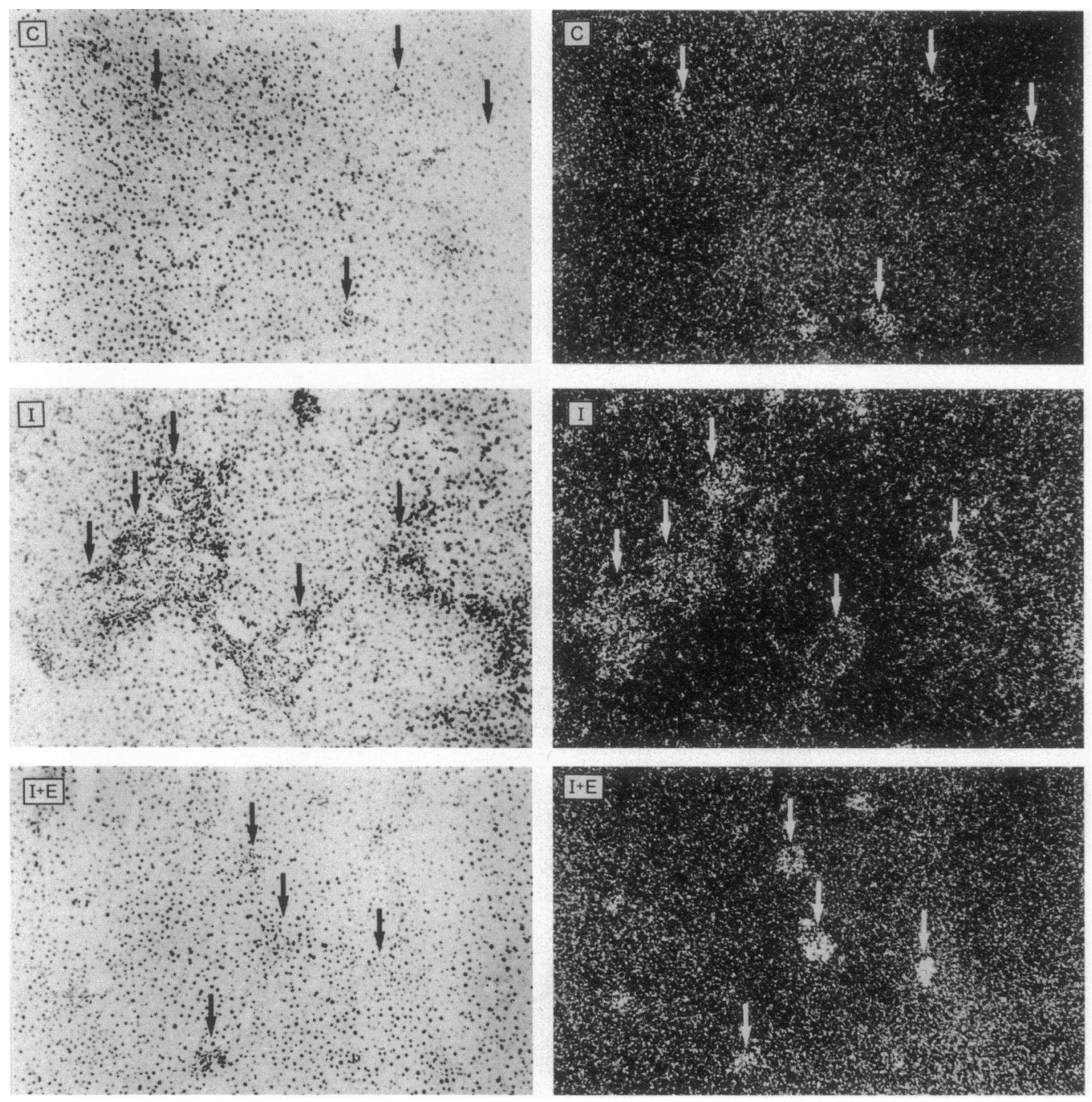

Figure 3. Localisation of TGF $\beta$ transcripts in iron-loaded gerbils. Liver tissue sections from control $(C)$ and iron-intoxicated gerbils on a standard $\operatorname{diet}(I)$ or on a vitamin-E enriched diet $(I+E)$ for 4 mo were processed for in situ hybridization analysis with a specific TGF $\beta{ }^{35} \mathrm{~S}$-cRNA probe synthesized in vitro using T7 RNA polymerase. Bright (left) and dark (right) field microphotographs are shown. Activation of TGF $\beta$ (arrows) is found in the stream of nonparenchymal cells around hepatocyte nodules $(I)$. In iron-treated gerbils on the vitamin $\mathrm{E}$ diet for 4 mo activation of the TGF $\beta$ gene is confined to the small iron-foci $(\mathrm{I}+\mathrm{E}) .(\times 106)$.

ization signal for collagen specifically accumulates on desminpositive cells around iron foci (Fig. $2 E$ ). The same occurs at 4 mo when a large number of FSC containing specific signal for collagen mRNA surrounds the nodules (not shown).

TGF $\beta$ represents one of the most important factors involved in liver fibrogenesis $(28,29)$. However, its role in liver fibrogenesis during iron-overload has not been investigated so far. In order to study the expression of TGF $\beta$ in the iron-treated gerbil, we used in situ hybridization analysis with a TGF $\beta$ cRNA probe. Fig. 3 shows that in iron-dosed gerbils a strong activation of TGF $\beta$ expression takes place into nonparenchymal cells surrounding hepatocyte nodule at 4 mo after dosing. Yet, some activation of TGF $\beta$ is also present into the small lesions of control gerbils (Fig. $3 \mathrm{C}$ ).

FSC proliferation. To study whether the effect of iron on activation of FSC was also due to a mitogenic effect exerted on FSC, as described in a different model of hepatic fibrosis (30), we performed in vivo labeling experiments with $\left[{ }^{3} \mathrm{H}\right]$ thymidine combined with immunocytochemistry with anti-desmin antibody. Results of a representative experiment are shown in Fig. 4. The presence of iron into the foci determines a strong proliferation of nonparenchymal cells, including FSC (Fig. 4 $B$ ). The percentage of proliferating FSC (i.e., number of desmin-positive cells with autoradiographic grains above the nucleus divided by the total number of desmin-positive cells $\times 100$ ) was $6.8 \pm 3$ in group a as compared with $0.6 \pm 0.3$ in group b. Proliferation of small desmin-negative cells with large nuclei resembling macrophagic cells was dramatically enhanced by iron-treatment (Fig. 4, $B$ and $C$ ). The main cells incorporating thymidine were macrophages and Kupffer cells. In fact, the percentage of the total proliferating cells corresponding to FSC ranged from 8 to $13 \%$ in iron-treated gerbils. Often, the proliferating macrophagic cells were in close contact with FSC and were seen in large number in the cellular stream originating from the iron-foci and eventually surrounding the hepatocyte nodules (Fig. $4 C$ ).

\section{Effects of vitamin E dietary supplementation}

Since liver damage and hepatic fibrosis during iron overload are thought to be mediated by iron-induced free radical species 

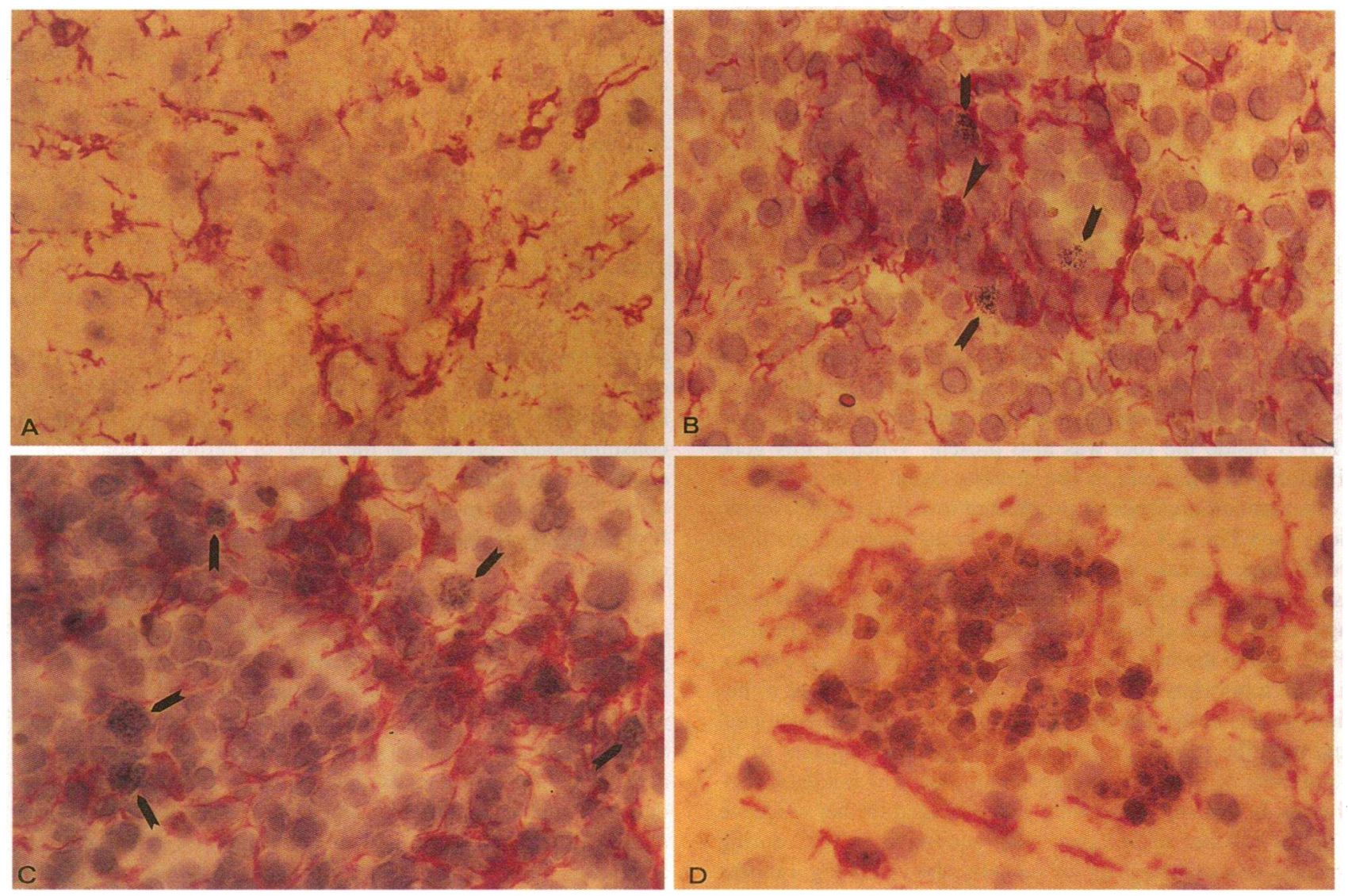

Figure 4. In vivo labeling of nonparenchymal cells in iron-treated gerbils. Gerbils were injected intravenously with $100 \mu \mathrm{Ci} / 100 \mathrm{gm}$ body wt of methyl- $\left[{ }^{3} \mathrm{H}\right]$ thymidine (specific activity $\left.6.7 \mathrm{Ci} / \mathrm{mmol}\right) 60 \mathrm{~min}$ before killing and liver tissue sections from control $(A)$ and iron-intoxicated gerbils on a standard diet $(B$ and $C$ ) or on a vitamin-E enriched diet $(D)$ were processed for immunocytochemistry with desmin antibody followed by autoradiography. The presence of iron into the foci causes a strong proliferation of nonparenchymal cells including FSC $($ arrowhead $)(B)$ and other desmin-negative cells resembling macrophagic cells (arrows), which largely contribute to the cellular stream originating from the iron-foci and eventually surrounding the hepatocyte nodules $(C)$. Dietary vitamin-E supplementation completely abolishes the proliferation of nonparenchymal cells inside and nearby the iron-filled foci $(D)$. $(C$ and $D, \times 655 ; A$ and $B, \times 425)$.

or lipid peroxidation by-products (7), we tested in vivo the effect of an anti-oxidant treatment on the molecular and pathological progression of the liver disease in the iron-dosed gerbil. As shown in Fig. 1, in spite of the fact that a comparable liver iron burden was reached in animals of group a and c ( see Table I), the hepatic histological pattern of iron-treated gerbils on the vitamin $\mathrm{E}$ enriched diet was totally different from that of irontreated gerbils on the standard diet. In fact, in iron-dosed vitamin E-fed gerbils liver pathology remained substantially unchanged throughout the study and at 4 mo it was not different from that of control gerbils, except that excess iron was present in the nonparenchymal cell aggregates (Fig. $1 D$ ). As predicted on the basis of the macro- and microscopical appearance of the liver, the deposition of collagen in iron-treated gerbils was greatly diminished by vitamin E supplementation (Table I). The in situ hybridization study showed that in these animals after 4 mo of iron-treatment activation of collagen gene was only present in small iron-filled foci scattered throughout the hepatic lobule (Fig. $2 F$ ), in contrast with the extensive expression of collagen gene in the large bundles of FSC surrounding the nodules seen at the same time-point in iron-treated gerbils on the standard diet (Fig. $2 \mathrm{D}$ ). This made a significant difference in terms of total amount of collagen mRNA expressed in the whole liver which, in fact, was significantly depressed by feeding iron-dosed animals with vitamin $\mathrm{E}$ for 4 mo (Table I). Yet, TGF $\beta$ expression showed the same expression pattern of the collagen gene in vitamin E-fed iron-treated gerbils, being detectable at 4 mo only in the small iron-foci (Fig. 3 ). In these animals, however, the most striking finding was the absence of proliferation of nonparenchymal cells, including FSC, as compared to the iron-treated animals on the standard diet (Fig. $4 D$ ). The percentage of proliferating FSC in these animals was $0.5 \pm 0.3$. The same molecular results were obtained with a group of gerbils $(n=8)$ which were fed a vitamin E enriched diet for 10 days before receiving iron injection and continuing on the vitamin E-enriched diet for 4 mo.

\section{Discussion}

Parenteral iron overload in the gerbil leads to hepatic cirrhosis $(9,14)$. The pattern of iron distribution in the liver of ironloaded gerbils resembles that of secondary iron overload states, the metal being mainly present into nonparenchymal cell foci, although a substantial amount of iron is also found in parenchymal cells. However, a series of considerations makes this model of special interest for the study of the general process of liver fibrogenesis during iron overload. First, in GH hepatic fibrosis appears only after iron overload of Kupffer cells following sid- 
eronecrosis of periportal hepatocytes occurs (2). Yet, by simply loading nonparenchymal cell with iron salts in the absence of hepatocellular necrosis, we were unable to show activation of collagen type I gene (31). Thus, during hepatic iron overload, activation of Kupffer cells by a necrotic event might be required for initiation of the fibrogenic process. In this respect, the ironloaded gerbil offers us the unique opportunity of studying the fibrogenic effect of iron overload in association with activation of Kupffer cells by microscopic necrotic events. In fact, gut endotoxin lipopolisaccarides cause small hemorragic lesions in the liver of the gerbil (14) followed by iron deposition (see also Fig. $1 A$ ). As a result, in control gerbils we found that the basal level of serum transaminases was slightly elevated and a sensible activation of collagen gene around the largest foci and of TGF $\beta$ inside the foci was also present. Whether this gene activation was only due to the necrotic event "per se" or to the concomitant presence of prooxidant iron in the microscopic lesions (see Fig. $1 A$ ), is unknown. On the contrary, the presence of large excess of iron after parenteral administration in these foci containing necrotic hepatocytes and activated macrophagic cells was responsible for recruitment of a large number of FSC around the foci and for enhanced accumulation of collagen gene transcripts in these cells, which eventually led to hepatic cirrhosis in the absence of additional necrotic phenomena. Thus, here the triggering factor of fibrogenesis appears to be the presence of iron into aggregates of activated nonparenchymal cells. In this study, we have also provided further evidence for the occurrence of collagen gene activation in FSC during parenteral iron overload, as we recently showed using a model of enteral iron intoxication in the rat (6). Thus, regardless of the localisation of excess iron in the liver, FSC are the major effectors of liver fibrogenesis during iron overload. At later stages of intoxication, in the absence of additional necrotic events (see Table I), a stream of collagen expressing FSC surrounds nodules of residual hepatocytes. In vivo labeling of liver cells with $\left[{ }^{3} \mathrm{H}\right]$ thymidine showed that the presence of iron into necrotic foci dramatically enhanced the proliferation of non-parenchymal cells into and nearby the foci. Some of these proliferating cells were desmin-positive while the majority were not. The desmin-negative cells had the morphological appearance of macrophagic cells. These cells eventually originated large bundles of proliferating cells which invaded liver parenchyma and entrapped nodules of residual hepatocytes. Interestingly, collagen expressing FSC were consistently found on the edge of the bundles of proliferating macrophagic cells or in tight contact with them.

Vitamin E dietary supplementation had a dramatic effect on the progression of hepatic fibrosis due to iron overload. In irontreated animals on the vitamin E supplemented diet, liver cirrhosis was totally prevented. This effect was even more impressive of that obtained by a vitamin E-enriched diet in $\mathrm{CCl}_{4}$-treated rats (32), in which vitamin E supplementation diminished necrotic events and gave raise to a cirrhotic liver with thinner septa as compared to $\mathrm{CCl}_{4}$-treated rats on a standard diet. According to our study, it seems that iron (or iron-generated free radical species) induces hepatic fibrosis through enhancement of collagen gene activity in FSC in concomitance with a strong mitogenic effect exerted on these cells and, mainly, on other nonparenchymal cells. The activation of collagen gene may be due to higher expression of fibrogenic factors, such as TGF $\beta$, which specifically occurred in nonparenchymal cells forming the ironfoci or invading the hepatic lobule and surrounding the hepatocyte nodules. However, the possibility that iron-induced free- radical species contributed to the activation of collagen gene, as suggested (6), cannot be ruled out. In fact, the antifibrogenic effect exerted by vitamin E supplementation was concomitant with a significant decrease in MDA production in the liver of iron-treated animals as compared to iron-treated animals on the standard diet. Nevertheless, a key role in the fibrogenic process induced by iron must be played by the enhanced proliferation of nonparenchymal cells, including FSC. Fibrogenic factors, particularly $\operatorname{TGF} \beta$, produced by the rapidly growing population of macrophagic cells might then be responsible for activation of collagen gene in FSC $(33,34)$. If the macrophagic cell population will not expand, no progression toward cirrhosis will occur and collagen or TGF $\beta$ expression will be confined to the basic hepatic lesion (i.e., microscopic iron-foci), which are constitutionally present in the liver of gerbils when kept in captivity. This was the picture found in control gerbils observed up to $14 \mathrm{mo}$ and in iron-treated gerbils on the vitamin $\mathrm{E}$ diet. In fact, none of these animals developed hepatic fibrosis or cirrhosis.

In conclusion, by using the iron-intoxicated gerbils, we were able to dissect the molecular events which underlie the fibrogenic potential of iron. The concept of the requirement of Kupffer cell activation by a toxic (necrogenic) event for initiation of the fibrogenic process fits well with the findings in $\mathrm{GH}$, in which iron itself leads to (sidero) necrosis of hepatocytes and activation of Kupffer cells. Interestingly, morphological evidence of microinflammation and Ito cell activation have been recently found in livers of patients with $\mathrm{GH}$ (35). In this respect, activation of FSC by Kupffer cells has a central role in the general process of liver fibrogenesis $(36,37)$. Moreover, the present study also indicates the potential role of iron in the progression of chronic liver disease when the effect of iron overload is concomitant with that of other hepatotoxins (e.g., alcohol, hepatitis viruses) which are able to initiate a damaging and/or necrogenic event in the liver. Our study shows that antioxidant treatment arrests fibrogenesis and completely prevents hepatic cirrhosis due to iron overload. This effect of vitamin $\mathrm{E}$ supplementation seems to be mainly due to a blocking activity exerted on hepatic nonparenchymal (i.e. macrophagic cells and FSC) proliferation triggered by iron. Whether the mitogenic effect of iron is direct (i.e., induced by iron or iron-generated free radical species) or mediated by growth factors (38-40) released by iron-filled nonparenchymal cells in response to the oxidative stress, is presently unknown. Future studies will attempt to identify these molecular species whose synthesis and/ or function is counteracted by antioxidant treatment in vivo, and which are ultimately responsible for this novel effect of iron on nonparenchymal cell proliferation during liver fibrogenesis.

\section{Acknowledgments}

This work was supported by a grant from the Progetto Nazionale Cirrosi Epatica ed Epatiti Virali del Ministero della Universita' e della Ricerca Scientifica e Tecnologica.

\section{References}

1. Bonkovsky, H. L. 1991. Iron and the liver. Am. J. Med. Sci. 301:32-43.

2. Deugnier, Y. M., O. Loréal, B. Turlin, D. Guyader, H. Jouanolle, R. Moirand, C. Jacquelinet, and P. Brissot. 1992. Liver pathology in genetic hemochromatosis: A review of 135 homozygous cases and their bioclinical correlations. Gas troenterology. 102:2050-2059.

3. Tavill, A. S., B. K. Sharma, and B. R. Bacon. 1990. Iron and the liver: genetic hemochromatosis and other hepatic iron overload disorders. Prog. Liver Dis. 9:281-305. 
4. Weintraub, L. R., A. Goral, J. Grasso, C. Franzblau, A. Sullivan, and S. Sullivan. 1988. Collagen biosynthesis in iron overload. Ann. N. Y. Acad. Sci. 526:179-184.

5. Pietrangelo, A., E. Rocchi, L. Schiaffonati, E. Ventura, and G. Cairo. 1990. Liver gene expression during chronic dietary iron overload in rats. Hepatology. 11:798-804.

6. Pietrangelo, A., R. Gualdi, G. Casalgrandi, A. Geerts, P. De Bleser, G. Montosi, and E. Ventura. 1994. Enhanced hepatic collagen type I mRNA expression into fat-storing cells in a rodent model of hemochromatosis. Hepatology. 19:714-721.

7. Bacon, B. R., and R. S. Britton. 1990. The pathology of hepatic iron overload: a free radical-mediated process? Hepatology. 11:127-137.

8. Chojkier, M., K. Houglum, J. Solis-Herruzo, and D. A. Brenner. 1989. Stimulation of collagen gene expression by ascorbic acid in cultured human fibroblasts. J. Biol. Chem. 264:16957-16962.

9. Iancu, T. C., H. Rabinowitz, P. Brissot, A. Guillouzo, Y. Deugnier, and M. Bourel. 1985. Iron overload of the liver in the baboon. An ultrastructural study. J. Hepatol. 1:261-275.

10. Weintraub, L. R., A. Goral, J. Grasso, C. Franzblau, A. Sullivan, and S. Sullivan. 1985. Pathogenesis of hepatic fibrosis in experimental iron overload. Br. J. Haematol. 59:321-331.

11. Park, C. H., B. R. Bacon, G. M. Brittenham, and A. S. Tavill. 1987. Pathology of dietary carbonyl iron overload in rats. Lab. Invest. 57:555-563.

12. Brissot, P., J. Farjanel, D. Bourel, J. P. Campion, A. Guillouzo, A. Rattner, Y. Deugnier, B. Desvergne, B. Ferrand, M. Simon, and M. Bourel. 1987. Chronic liver iron overload in the baboon by ferric nitrilotriacetate. Morphologic and functional changes with special reference to collagen synthesis enzymes. Dig. Dis. Sci. 32:620-627.

13. Carthew, P., R. E. Edwards, A. G. Smith, B. Dorman, and J. E. Francis. 1991. Rapid induction of hepatic fibrosis in the gerbil after the parenteral administration of iron-dextran complex. Hepatology. 13:534-539.

14. Carthew, P., R. E. Edwards, and B. M. Dorman. 1991. Hepatic fibrosis and iron accumulation due to endotoxin-induced haemorrhage in the gerbil. $J$. Comp. Pathol. 104:303-311.

15. Carthew, P., B. M. Dorman, R. E. Edwards, J. E. Francis, and A. G. Smith. 1993. A Unique Rodent Model for Both the Cardiotoxic and Hepatotoxic Effects of Prolonged Iron Overload. Lab. Invest. 69:217-222.

16. Genovese, C., D. Rowe, and B. Kream. 1984. Construction of DNA sequences complementary to rat $\alpha-_{-1}$ and $\alpha-2$ collagen mRNA and their use in studying the regulation of type I collagen synthesis by 1,25-dihydroxyvitamin D. Biochemistry. 23:6210-6216.

7. Milani, S., H. Herbst, D. Schuppan, E. G. Hahn, and H. Stein. 1989. In situ hybridization for procollagen types I, III and IV mRNA in normal and fibrotic rat liver: evidence for predominant expression in nonparenchymal liver cells. Hepatology. 10:84-92.

18. Derynck, R., J. A. Jarret, E. Y. Chen, D. H. Eaton, J. R. Bell, R. K. Assoian, A. B. Roberts, M. B. Sporn, and D. V. Goeddel. 1985. Human transforming growth factor- $\beta$ complementary DNA sequence and expression in normal and transformed cells. Nature (Lond.). 316:701-705.

19. Chomczynski, P., and N. Sacchi. 1987. Single-step method of RNA isolation by acid guanidinium thiocyanate-phenol-chloroform extraction. Anal. Biochem. 162:156-159.

20. Pietrangelo, A., E. Rocchi, G. Casalgrandi, G. Rigo, A. Ferrari, M. Perini, E. Ventura, and G. Cairo 1992. Regulation of transferrin, transferrin receptor, and ferritin genes in human duodenum. Gastroenterology. 102:802-809.

21. Pietrangelo, A., E. Rocchi, A. Ferrari, E. Ventura, and G. Cairo. 1991. Regulation of hepatic transferrin, transferrin receptor and ferritin genes in human siderosis. Hepatology. 14:1083-1089.

22. Arnheim, N., D. Treco, B. Taylor, and E. M. Eicher. 1982. Distribution of ribosomal gene length variants among mouse chromosomes. Proc. Natl. Acad. Sci. USA. 79:4677-4680.

23. Rocchi, E., P. Gibertini, M. Cassanelli, A. Pietrangelo, and E. Ventura. 1986. Serum ferritin in the assessment of liver iron removal therapy in porphyria cutanea tarda. J. Lab. Clin. Med. 107:36-42.

24. Rocchi, E., A. Borghi, F. Paolillo, M. Pradelli, and G. Casalgrandi. 1991. Carotenoids and liposoluble vitamins in liver cirrhosis. J. Lab. Clin. Med. 118:176-185.

25. Recknagel, R. O., E. A. Glende, R. L. Waller, and K. Lowrey. 1982. Lipid peroxidation: biochemistry, measurement, and significance in liver cell injury. In Toxicology of the liver. G. Plaa, and W. R. Hewitt editors. New York, Raven Press. 213-241.

26. Ala-Kokko, L., F. Stenback, and L. Ryhanen. 1989. Preventive effect of malotilate on dimethylnitrosamine-induced liver fibrosis in the rat. J. Lab. Clin. Med. 113:177-183.

27. Zender R. 1972. Analyse de l'hydroxyproline urinaire: methode e valeur frequentes. Clin. Chim. Acta. 37:263-270.

28. Friedman, S. L. 1993. The cellular basis of hepatic fibrosis. Mechanisms and treatment strategies. N. Engl. J. Med. 328:1828-1835.

29. Armendariz-Borunda, J., K. Katayama, and J. M. Seyer. 1992. Transcriptional mechanisms of type I collagen gene expression are differentially regulated by interleukin-1 beta, tumor necrosis factor alpha, and transforming growth factor beta in Ito cells. J. Biol. Chem. 267:14316-14321.

30. Geerts, A., J-M. Lazou, P. De Blesier, and E. Wisse. 1991. Tissue distribution, quantitation and proliferation kinetics of fat-storing cells in carbon tetrachloride-injured rat liver. Hepatology. 13:1193-1202.

31. Pietrangelo, A., R. Gualdi, G. Casalgrandi, G. Montosi, and E. Ventura. 1994. Hepatocellular iron-loading is required for collagen type I gene activation in experimental siderosis. Gastroenterology. 107:1118-1124.

32. Parola, M., G. Leonarduzzi, F. Biasi, E. Albano, M. E. Biocca, G. Poli, and M. U. Dianzani. 1992. Vitamin E dietary supplementation protects against carbon tetrachloride-induced chronic liver damage and cirrhosis. Hepatology. 16:1014-1021

33. Weiner, F. R., M. A. Giambrone, M. J. Czaja, A. Shah, G. Annoni, S Takahashi, M. Eghbali, and M. A. Zern. 1990. Ito cell gene expression and collagen regulation. Hepatology. 11:111-117.

34. Bachem, M. G., D. Meyer, R. Melchior, K-M. Sell, and A. M. Gressner 1992. Activation of rat liver perisinusoidal lipocytes by transforming growt factors beta 1 on cell proliferation and collagen formation by cultured fat-storing cells. J. Clin. Invest. 89:19-27.

35. Hulcrantz, R., P. Stal, and A. Scheynius. 1994. Evidence of microinflammation and ito-cell activation in iron overloaded hepatocytes in patients with hemochromatosis. Proceedings of the European Iron Club '94, Gargnano del Garda, Italy. A18.

36. Friedman, S. L and M. J. P. Arthur 1989. Activation of cultured rat hepatic lipocytes by Kupffer cell conditioned medium: direct enhancement of matrix synthesis and stimulation of cell proliferation via induction of plateletderived growth factor receptors. J. Clin. Invest. 84:1780-1785.

37. Friedman, S. L., S. Wei, and W. S. Blaner. 1993. Retinol release by activated hepatic lipocytes: regulation by Kupffer cell-conditioned medium and PDGF. Am. J. Physiol. 264:G947-G952.

38. Rojkind, M., and G. Valadez. 1985. Regulation of fibroblasts proliferation by Kupffer cells and monocytes. In: Fibrosis, Ciba Foundation Symposium 114. London, Pitman 208-215.

39. Shiratori, Y., A. Geerts, T. Ichida, T. Kawase, and E. Wisse. 1986. Kupffe cells from CC14-induced fibrotic livers stimulate proliferation of fat-storing cells. J. Hepatol. 3:294-303.

40. Armendariz-Borunda, J., P. Greenwel, and M. Rojkind. 1989. Kupffer cells from CC14-treated rat liver induce skin fibroblasts and liver fat-storing cell proliferation in culture. Matrix. 9:150-158. 